\title{
Brief Communication: Cetaceans and tsunamis - whatever remains, however improbable, must be the truth?
}

\author{
J. R. Goff and C. Chagué-Goff \\ Australian Tsunami Research Centre, School of Biological, Earth, and Environmental Sciences, University of New South \\ Wales, Sydney 2052, Australia
}

Received: 26 February 2009 - Revised: 25 May 2009 - Accepted: 1 June 2009 - Published: 15 June 2009

\begin{abstract}
The composition of tsunami deposits is variable and governed by source material. Many unusual items have been recorded from tsunami deposits. For example, during the 2004 Indian Ocean Tsunami, a dolphin was reported to have been transported $1400 \mathrm{~m}$ inland, a shark was found in a hotel swimming pool, and sea turtles were stranded kilometers inland. Reports and papers from early settlers and explorers have often highlighted similar unusual finds. We briefly discuss an example from New Zealand where intact cetacean skeletons were found elevated on land adjacent to the coast. The validity of this find as evidence for tsunami emplacement is considered. It is also noted that such old reports should be treated with respect and re-evaluated in the light of more recent findings.
\end{abstract}

\section{Brief communication}

Sedimentological, biological and geochemical evidence from historic tsunamis provides valuable information for researchers attempting to identify records of prehistoric events. For example, in addition to fine sediments, there are numerous historically-documented reports of limestone megaclasts (e.g. Noormets et al., 2004), fish (e.g. Lander et al., 2003) and large organic debris including mature trees (e.g. McSaveney et al., 2000) being carried inland by tsunamis. It was therefore not surprising that during the 2004 Indian Ocean Tsunami (2004 IOT) an Indo-Pacific Humpback dolphin (Sousa chinensis) was washed $1400 \mathrm{~m}$ inland over a 4-5 m high embankment at Phuket (Anon., 2009a; Stachowitsch et al., 2005) and a shark ended up in a hotel swimming pool near Khao Lak, Thailand (ASC, 2005; Owen, 2009), and that sea turtles were found washed up in ponds kilometers inland in SE Sri Lanka (Anon., 2009b).

Correspondence to: J. R. Goff

(j.goff@unsw.edu.au)
Unfortunately, much of the physical evidence of any tsunami starts to deteriorate immediately after inundation. Subtle indicators of inundation such as bent grass, salt-burnt vegetation, and stranded fish, are normally rapidly lost. Over time, taphonomic processes remove much, often all, evidence of organic material, and further deterioration of the tsunami evidence occurs through processes such as sediment bioturbation and erosion (Horton et al., 2006). In many cases, evidence is sufficiently incomplete or rare to make a definitive identification impossible (e.g. Goff et al., 2000).

In the case of the potential organic evidence that might have been provided by the Indo-Pacific Humpback dolphin, it was removed (rescued) and returned to the sea alive thus preventing its subsequent skeletal remains representing something of an anomalous find so far from the ocean. Furthermore, many one-way turtle tracks were reported by the survey team in Sri Lanka, indicating that turtles had made their way back to the sea. Such anomalous observations do exist, and were often reported by early settlers or scientists in a region. In many cases the observations are known, but most are ignored or have never been re-evaluated in the light of more recent findings. For example, McLeod (1912) reported " $a$ number of cetacean skeletons, crumbling to powder, yet preserved in form in dry sand, lie at heights up to $147 \mathrm{ft}$ above high water mark. One, stretching over 60ft, is half a mile inland." This was on Miramar Peninsula, on the south coast of Wellington, New Zealand.

There are several important points here. First, they are intact skeletons, not bones, and therefore highly unlikely (impossible) to have been carried there by early sealers or prehistoric Maori (Anon., 1908). Second, neither author makes reference to the skeletons having been cut up or altered by human activity, which would suggest that they were deposited there prior to human arrival. Third, the skeletons were preserved in mobile sands (Anon., 1908), which most likely means that they are of Holocene age.

Published by Copernicus Publications on behalf of the European Geosciences Union. 
It is difficult to avoid an element of circularity but it is assumed that the whales were somehow emplaced there by the sea (a logical conclusion?). The contemporary coast is cliffed with a few uplifted beaches, but the present sea level approximates that of about 7000 years ago (Gibb, 1986). An older Holocene age would put the sea level lower, making any possible scenario for emplacement of the whales less plausible. There has been at least $8.5 \mathrm{~m}$ of uplift in 7000 years, a mean rate of $1.2 \mathrm{~m}$ per 1000 years (Pillans and Huber, 1995). The whale remains must have been transported to an elevation of around $35 \mathrm{~m}$ [maximum whale elevation of $147 \mathrm{ft}$ or about $45 \mathrm{~m}$ (based on McLeod, 1912) less $10 \mathrm{~m}$ of uplift in 7000 years (rounded up to a slightly more rapid rate than that proposed by Pillans and Huber, 1995)]. The distance inland of the highest elevation site is approximately $500 \mathrm{~m}$ (from contemporary and uplifted shorelines).

The taphonomy of whale bones is highly variable, but in exposed coastal sites it rarely lasts beyond 50 years (Liebig et al., 2003). It seems likely therefore that the skeletons must have been rapidly covered with sand, or have been incorporated within it at the time of deposition. Perhaps the sand in which they were buried was a tsunami deposit and not a windblown dune?

If this was the result of a (very large) tsunami-which seems to be the only plausible explanation-why has no one ever found evidence for this event before? The answer is that the whales and associated sand might have been the only obvious evidence, and the site has now been built on. At the time however, it was observed that "If the whales were washed there then one of two hypotheses may be accepted: that a tidal wave (sic) carried the carcasses far inshore, or that the land has been raised with the embedded carcasses in it" (Anon., 1908). This is a remarkably interesting statement given that research into prehistoric tsunamis (tidal waves) did not commence in the modern era until the late 1980s (Atwater, 1987). It is also remarkable because we now know that part of the explanation is indeed uplift. Could the second part of the explanation be a tsunami?

It is difficult to consider this possibility without some knowledge of a potential source, although equally it is difficult to find an alternative explanation. Recent research in the $1200 \mathrm{~m}$ deep Cook Strait Canyon has revealed widespread submarine landsliding offshore of Miramar Peninsula (Mountjoy et al., 2009). There are now therefore several potential sources, but are they of the correct age or size capable of creating a large enough tsunami? The simple answer at the moment is that we don't know, but we can at least look to recent events as a guide.

First, it is important to infer the most likely type of cetacean being transported in this instance. Cook Strait has long been recognised as a major sea route for the Sperm Whale (Physeter macrocephalus L.) (Hutching, 2009). Sperm whales tend to travel in groups ["a number of cetacean skeletons" (McLeod, 1912) were found] and the average bull is about $16 \mathrm{~m}$ long ["stretching over
$60 \mathrm{ft}$ " (McLeod, 1912) or about $18 \mathrm{~m}]$. Mature sperm whales have an average weight of around $41000 \mathrm{~kg} \mathrm{(41} \mathrm{t)} \mathrm{(Hutching,}$ 2009). In comparison, adult Indo-Pacific Humpback dolphins (those carried inland by the 2004 IOT) are up to 2.0 $2.8 \mathrm{~m}$ long and weigh up to $280 \mathrm{~kg}$ (Ross et al., 1994), and thus are considerably smaller. It does not however, require a large tsunami to move large objects around. The $1994 \mathrm{Min}-$ doro Philippines tsunami transported a 4000 ton barge $1.5 \mathrm{~km}$ inland, but the maximum runup did not exceed $4.5 \mathrm{~m}$ (Imamura et al., 1995). The 2004 IOT carried many ships and smaller vessels inland, but why did we not see the stranding of large cetaceans? The most reasonable answer appears to be that far from being unable to transport them, there were none to transport.

The discovery of the whales of Miramar Peninsula leaves us with three important messages. First, it is plausible to infer their emplacement by tsunami; second, this case seems to indicate an extremely unfortunate coincidence whereby whales happened to be in the wrong place at the wrong time; and third, we should treat old papers and reports with respectthere are many of them, they are rarely cited, and they saw it first.

Sadly, the whale skeleton site of Miramar Peninsula was destroyed to make way for a residential sub-division.

Edited by: S. Tinti

Reviewed by: W. Dudley, G. A. Mastronuzzi, and C. Sloss

\section{References}

Anonymous: Miramar Relics, Evening Post, LXXVI, 108, 3 November, p. 4, 1908.

Anonymous: http://www.smh.com.au/news/Asia-Tsunami/ Rescue-stalled-for-dolphins-swept-inland/2005/01/04/ 1104832107684.html, access: 26 February 2009, 2009a.

Anonymous: http://www.nature.org/pressroom/press/press1797. html, access: 19 May 2009, 2009b.

Amateur Seismic Centre (ASC): http://asc-india.org/lib/ 20041226-sumatra.htm, access: 19 May 2009.

Atwater, B. F.: Evidence for great Holocene earthquakes along the outer coast of Washington State, Science, 236, 942-944, 1987.

Gibb, J. G.: A New Zealand regional Holocene eustatic sea-level curve and its application to determination of vertical tectonic movements, Bull. Roy. Soc. NZ, 24, 377-395, 1986.

Goff, J. R., Rouse, H. L., Jones, S., Hayward, B., Cochran, U., McLea, W., Dickinson, W. W., and Morley, M. S.: Evidence for an earthquake and tsunami about 3100-3400 years ago, and other catastrophic saltwater inundations recorded in a coastal lagoon, New Zealand, Mar. Geol., 170, 233-251, 2000.

Horton, B. P., Hawkes, A., Engelhart, S., Bird, M., Cowie, S., Eong Ong, J., Tan Shau Hwai, A., Law, L., MacGregor, C., Tiong Sa, T., and Yasin, Z.: The Taphonomy of Sediments Deposited by the Indian Ocean Tsunami Along the West Coast of the Malay-Thai Peninsula, AGU, abstract PP43B-1237, 2006.

Hutching, G.: http://www.TeAra.govt.nz/EarthSeaAndSky/ SeaLife/Whales/en, access 25 February 2009. 
Imamura, F., Synolakis, C. E., Gica, E., Titov, V., Listanco, E., and Lee, H. J.: Field survey of the 1994 Mindoro Island, Philippines Tsunami. Pure App. Geoph., 144, 3-4, 875-890, 1995.

Lander, J. F., Whiteside, L. S., and Lockridge, P. A.: Two Decades of Global Tsunamis, 1982-2002, Sci. Tsu. Haz., 21(1), 3-82, 2003.

Liebig, P. M., Taylor, T. S. A., and Flessa, K. W.: Bones on the Beach: Marine Mammal Taphonomy of the Colorado Delta, Mexico, Palaios, 18, 168-175, 2003.

McLeod, H. N.: Pre-Pakeha occupation of Wellington District, Early Settlers \& Hist. Assoc. Wellington Journal, 1, 14-17, 1912.

McSaveney, M., Goff, J., Darby, D., Goldsmith, P., Barnett, A., Elliott, S., and Nongkas, M.: The 17th July 1998 Tsunami, Sissano Lagoon, Papua New Guinea-evidence and initial interpretation, Mar. Geol., 170, 81-92, 2000.

Mountjoy, J. J., Barnes, P. M., and Pettinga, J. R.: Morphostructure and evolution of submarine canyons across an active margin: Cook Strait sector of the Hikurangi Margin, New Zealand, Mar. Geol., 260, 45-68, 2009.
Noormets, R., Crook, K. A. W., and Felton, E. A.: Sedimentology of rocky shorelines: 3. Hydrodynamics of megaclast emplacement and transport on a shore platform, Oahu, Hawaii, Sed. Geol., 172, 41-65, 2004.

Owen, J.: http://news.nationalgeographic.com/news/2005/01/0117_ 050119_tsunami_marine.html, access 19 May 2009.

Pillans B. and Huber, P.: Interpreting coseismic deformation using Holocene coastal deposits, Wellington, New Zealand, Quat. Int., 26, 87-95, 1995.

Ross, G. J. B., Heinsohn, G. E., and Cockcroft, V. G.: Humpback dolphins Sousa chinensis (Osbeck, 1765), Sousa plumbea (G. Cuvier, 1829) and Sousa teuszii (Kukenthal, 1892), in: Handbook of marine mammals; the first book of dolphins, Academic Press, London, UK, 5, 23-42, 1994.

Stachowitsch, M., Parsons, E. C. M., and Rose, N. A. (Eds.): State of the Cetacean Environment Report, International Whaling Commission Scientific Committee, Cambridge, UK, Report No. SC/57/E8, 2005. 